\title{
EFFECTS OF GYPSUM COMBINED WITH DIFFERENT AMOUNTS OF BIOCHEMICAL HUMIC ACID ON SOIL IMPROVEMENT AND COTTON (GOSSYPIUM HIRSUTUM L.) YIELD ON SALINE-ALKALI LAND
}

\author{
SHAN, Y. Y. ${ }^{1}-$ LI, G. ${ }^{1}-$ BAI, Y. G. ${ }^{3}-$ LIU, H. B. ${ }^{2,3^{*}}-$ ZHANG, J. H. ${ }^{1}-$ WEI, K. ${ }^{1}-$ WANG, Q. J. ${ }^{1}-$ \\ CAO, L. ${ }^{4}$ \\ ${ }^{I}$ State Key Laboratory of Eco-hydraulics in Northwest Arid Region of China, Xi'an University \\ of Technology, Xi'an 710048, China \\ ${ }^{2}$ College of Hydraulic and Civil Engineering of Xinjiang Agricultural University, Urumqi \\ 830052, China \\ ${ }^{3}$ Xinjiang Institute of Water Resources and Hydropower Research, Urumqi 830049, China \\ ${ }^{4}$ Shaanxi Fengxi Xincheng Investment Development Co., Ltd, Xi'an 710048, China \\ ${ }^{*}$ Corresponding author \\ e-mail: 82914024@qq.com \\ (Received $28^{\text {th }}$ Sep 2021; accepted $23^{\text {rd }}$ Nov 2021)
}

\begin{abstract}
This study was conducted to investigate the effects of gypsum combined with different amounts of biochemical humic acid (BHA) on the improvement of saline-alkali soil and cotton (Gossypium hirsutum L.) yield under film-mulched drip irrigation in Shaya County, Aksu Prefecture, Xinjiang, China. Using the micro zone test method, taking the single application of gypsum as the control (CK, gypsum $15 \mathrm{t} \cdot \mathrm{ha}^{-1}$ ), 3 ratios of BHA were applied: A (gypsum $15 \mathrm{t} \cdot \mathrm{ha}^{-1}+$ BHA $0.35 \mathrm{t} \cdot \mathrm{ha}^{-1}$ ), B (gypsum $15 \mathrm{t} \cdot \mathrm{ha}^{-1}+$ BHA $0.75 \mathrm{t}^{\mathrm{h}} \mathrm{ha}^{-1}$ ) and C (gypsum $15 \mathrm{t} \cdot \mathrm{ha}^{-1}+$ BHA $1.50 \mathrm{t} \cdot \mathrm{ha}^{-1}$ ). The results showed that the combined application of gypsum and BHA significantly reduced soil $\mathrm{pH}$ and electric conductibility, while increased soil porosity. Compared to the control, the large aggregates $(>0.25 \mathrm{~mm})$ in $0-10 \mathrm{~cm}$ and $10-20 \mathrm{~cm}$ soil layers of the three treatments increased by $10.00 \%, 20.33 \%, 33.68 \%$ and $7.39 \%, 20.61 \%$ and $25.00 \%$, respectively. Besides, the content of $\mathrm{Na}^{+}$in topsoil decreased significantly, while the content of $\mathrm{Mg}^{2+}$ increased obviously. In addition, the cotton yield increased by $5.86 \%, 12.50 \%$ and $18.13 \%$, respectively compared with the control. Considering the yield investment ratio of agricultural production and the comprehensive effect of soil improvement, the combined application mode of gypsum 15 tha ${ }^{-1}+$ biochemical humic acid $1.50 \mathrm{t}^{-\mathrm{ha}^{-1}}$ had the best result among all three treatments.
\end{abstract}

Keywords: humic acid, saline-alkali soil, soil structure, soil cation, cotton

\section{Introduction}

Due to the long-term unreasonable development and utilization of land and the unique geographical conditions of Xinjiang, China, the problem of soil salinization is becoming more and more serious (Heng et al., 2018; Liang et al., 2021). The area of saline-alkali wasteland in Xinjiang is $2.81 \times 10^{7}$ ha, accounting for about one-third of the total area of saline-alkali land in China (Yan et al., 2021; Zhou et al., 2021). Salinization has completely restricted the agricultural development and sustainable development of Xinjiang. Finding ways to eliminate the harm of salt and alkali to the greatest extent through comprehensive improvement measures is essential to ensure food security and sustainable agricultural development in Xinjiang, China. 
Gypsum has been proven to be an effective measure to improve saline-alkali soil (Wang et al., 2017a; Zhang et al., 2020). Wang et al. (2021) showed that the pH value, alkalinity, and total salt content of alkali soil decreased by $17.20 \%, 42.63 \%$ and $46.43 \%$, respectively three years after the application of gypsum. Mao et al. (2014) pointed out that the percentage of soil exchangeable sodium decreased significantly when gypsum was applied. Furthermore, the application of gypsum could promote the growth of rice seedlings and improve the survival rate of Lycium barbarum seedlings (Zhao et al., 2018; Liu et al., 2020). However, since gypsum itself is salt, the effect of improper application will be counterproductive. Sakai et al. (2004) found that excessive application of gypsum or poor management could cause soil salt accumulation and increase the total salt content of soil. Zhao et al. (2019) indicated that the application amount of gypsum was not as much as possible through indoor soil column tests. Therefore, by improving the application mode of gypsum, strengthening its improvement effect on saline-alkali soil and optimizing the application structure, so as to achieve the purpose of scientifically using coal-fired desulfurization waste to improve saline alkali soil. Zhao et al. (2020) found that the 1:1 combination of gypsum and humic acid reduced the soil $\mathrm{pH}$, significantly increased the content of available potassium, and increased the corn yield by $40 \%$. Nan et al. (2016) took the saline-alkali land in the northern coastal area of Jiangsu Province as the experimental area, and found that the effect of improving saline alkali with $3.2 \mathrm{t}^{\mathrm{h}} \mathrm{ha}^{-1}$ gypsum combined with $1.5 \mathrm{t} \cdot \mathrm{ha}^{-1}$ humic acid was the best, and the yield increasing effect of rape was obvious. Xia et al. (2019) pointed out that under the combined action of gypsum and humic acid, soil bulk density significantly decreased, and the emergence rate and yield of silage corn significantly increased.

This paper studied the effects of combined application of gypsum and different amounts of biochemical humic acid (BHA) on the physical and chemical properties of saline-alkali soil and cotton (Gossypium hirsutum L.) yield, and looked for the best ratio of gypsum and BHA, so as to reduce the required amount of gypsum and improve its saline-alkali soil improvement effect, so as to provide a reference for scientific and rational utilization of gypsum, and technical support and theoretical basis for the largescale popularization of using it to improve saline-alkali land in arid and semi-arid regions.

\section{Materials and methods}

\section{Overview of test area}

The experiment was conducted in Shaya County $\left(41^{\circ} 25^{\prime} \mathrm{N}, 84^{\circ} 47^{\prime} \mathrm{E}\right)$ in Aksu Prefecture, Xinjiang, China. This region is located in the south of the middle section of Tianshan Mountain, the north edge of Taklimakan Desert and the middle reaches of Tarim River, with an altitude of 946-1050 m. Moreover, the region is far from the sea, the East, South and West are surrounded by deserts, and the ecological environment is relatively fragile. In addition, the region is a typical continental warm temperate arid climate, with annual precipitation of $57.44 \mathrm{~mm}$, evaporation of $2756 \mathrm{~mm}$, average temperature of $11.32^{\circ} \mathrm{C}$, annual sunshine number of $2965 \mathrm{~h}$, wind speed of $2.54 \mathrm{~m} \cdot \mathrm{s}^{-1}$, and frost-free period of 148 days (Liang et al., 2021). Before the experiment, the physical and chemical properties of the initial soil were determined. The soil in the study area $(0-40 \mathrm{~cm})$ was sandy loam $(63.32 \%$ sand, $34.23 \%$ silt, $2.45 \%$ clay) saturated water content was $0.396 \mathrm{~cm}^{3} \cdot \mathrm{cm}^{-3}$, wilting water content was $0.048 \mathrm{~cm}^{3} \cdot \mathrm{cm}^{-3}$, field water capacity was $0.203 \mathrm{~cm}^{3} \cdot \mathrm{cm}^{-3}$ (Zhou et al., 2021). 


\section{Experimental design}

The micro zone test was carried out in the study area from April 22 to 28, 2019. A single factor completely randomized block design was adopted. Each treatment was set for 3 repetitions, and the area of each cell was $5 \mathrm{~m} \times 6 \mathrm{~m}\left(30 \mathrm{~m}^{2}\right)$. A total of 4 treatments were set as follows:

(1) CK (single application of gypsum $15 \mathrm{t} \cdot \mathrm{ha}^{-1}$ ),

(2) A (gypsum $15 \mathrm{t} \cdot \mathrm{ha}^{-1}+$ BHA $0.35 \mathrm{t} \cdot \mathrm{ha}^{-1}$ ),

(3) B (gypsum $15 \mathrm{t} \cdot \mathrm{ha}^{-1}+$ BHA $0.75 \mathrm{t} \cdot \mathrm{ha}^{-1}$ ),

(4) C (gypsum $15 \mathrm{t} \cdot \mathrm{ha}^{-1}+$ BHA $\left.1.50 \mathrm{t} \cdot \mathrm{ha}^{-1}\right)$.

Biochemical humic acid (BHA) is produced by Beijing Aojia Ecological Agriculture Co., Ltd. After gypsum and BHA were evenly spread in each community, the harrow was carried out with a disc harrow, and the harrow depth was $0-20 \mathrm{~cm}$. The cotton was cultivated by drip irrigation under film, and the cultivation mode was $1 \mathrm{film}, 2$ tubes and 6 rows. The field management level in the later stage of treatment was the same. Conventional irrigation was adopted in the whole growth period of cotton, and the irrigation amount was consistent with the actual production. The irrigation quota of cotton growth period was $5700 \mathrm{~m}^{3} \cdot \mathrm{ha}^{-1}$, the irrigation period was 7-10 days, and the total irrigation time was 9 times. The soil conditions of the test site before the test were shown in Table 1.

Table 1. The condition of soil in the study area

\begin{tabular}{|c|c|c|c|c|c|c|c|}
\hline pH & $\begin{array}{c}\text { Electric } \\
\text { conductibility } \\
\left(\mathbf{d S} \cdot \mathbf{m}^{-1}\right)\end{array}$ & $\begin{array}{l}\text { Bulk } \\
\text { density } \\
\left(\mathrm{g} \cdot \mathrm{kg}^{-3}\right)\end{array}$ & $\begin{array}{c}\text { Alkalinity } \\
(\%)\end{array}$ & $\begin{array}{c}\text { Available } \\
\text { phosphorus } \\
\left(\mathbf{m g}^{\circ} \cdot \mathbf{k g}^{-1}\right)\end{array}$ & $\begin{array}{c}\text { Tatal } \\
\text { phosphorus } \\
\left(\mathrm{g}^{\circ} \mathbf{k g}^{-1}\right)\end{array}$ & $\begin{array}{c}\text { Alkali-hydrolyzed } \\
\text { nitrogen } \\
\left(\mathbf{m g} \cdot \mathbf{k g}^{-1}\right)\end{array}$ & $\begin{array}{l}\text { Organic } \\
\text { matter } \\
\left(\mathrm{g}^{\circ} \mathrm{kg}^{-1}\right)\end{array}$ \\
\hline 8.9 & 1.87 & 1.63 & 10.8 & 11.23 & 0.35 & 38.49 & 9.35 \\
\hline
\end{tabular}

\section{Investigate items and methods}

On September 20, 2019, the soil in the harvested cotton field was sampled. Three sections $(60 \mathrm{~cm})$ were randomly excavated in each plot, and soil samples of 0-10, 10-20, 20-40 and 40-60 cm were collected, respectively. The soil samples of the same soil layer at the three sample points were evenly mixed, and the collected soil was brought back to the laboratory for natural air drying and pass through $1 \mathrm{~mm}$ sieve. The 0-10, 10-20, 20-40 and 40-60 cm soil samples of the test field were collected in plastic boxes, respectively. The soil samples were brought back to the laboratory and dried at room temperature. After the samples reached the plastic limit (about 20\% water content), they would be sieved through $8 \mathrm{~mm}$ sieve for aggregate analysis.

The composition and distribution of soil aggregates were determined by dry sieving method. During air drying, the soil samples was gently broken into small soil blocks with a diameter of about $1 \mathrm{~cm}^{3}$ along with the natural structure of the soil. The plant roots and stones in soil samples were removed. The soil samples (100 g, three replicates) were passed through a set of screen groups with a diameter of $30 \mathrm{~cm}$. The pore sizes of the sieve were $8,5,2,1,0.25 \mathrm{~mm}$ and $0.053 \mathrm{~mm}$, respectively. There was a cover above the screen group and a bottom below the screen group. The screening time shall be controlled as 10 min. after screening, the weight of soil sample on the sieve of each aperture was 
measured. The soil $\mathrm{pH}$ value was measured by BPH $252 \mathrm{pH}$ meter (soil water ratio 1:2.5, $\mathrm{HACH}, \mathrm{USA}$ ). The soil electric conductivity was determined by DDSJ-308A electric conductivity meter (soil water ratio 1:5, Shanghai Yifen Scientific Instrument Co., Ltd, China). The contents of $\mathrm{K}^{+}, \mathrm{Ca}^{2+}, \mathrm{Na}^{+}, \mathrm{Mg}^{2+}$ in soil samples were determined by ICP (plasma emission spectrometry, SPECK, Germany).

On September 15, 2019, the cotton yield under each treatment in the experimental plot of the study area was measured. 3 sample points were taken from each community. 11 lines were taken from each sample point to measure the line spacing and calculate the average line spacing. 21 plants in one row were randomly selected from each sample point to measure the plant spacing and calculate the average plant spacing. 3 rows were randomly selected from each sample point, 10 plants in each row, a total of 30 plants, and the number of bolls was investigated. 100 bolls were collected randomly at each sample point to weigh them after drying and calculate the average single boll weight. Cotton yield was calculated by the average line spacing, plant spacing, number of bolls per plant and average single boll weight.

\section{Composition of gypsum}

The gypsum used in the test was provided by the Huadian Xinjiang Power Generation Co., Ltd. The main component of gypsum is $\mathrm{CaSO}_{4} \cdot 2 \mathrm{H}_{2} \mathrm{O}$, with a content of $74.76 \%$, and water content $38.23 \%$, pH value 7.36 , electric conductivity $2.84 \mathrm{dS} \cdot \mathrm{m}^{-1}$, total salt content $16 \mathrm{~g} \cdot \mathrm{kg}^{-1}, \mathrm{~K}$ content $5.39 \mathrm{~g} \cdot \mathrm{kg}^{-1}, \mathrm{Na}$ content $12.35 \mathrm{~g} \cdot \mathrm{kg}^{-1}$, Ca content $226.71 \mathrm{~g} \cdot \mathrm{kg}^{-1}, \mathrm{Mg}$ content $4.16 \mathrm{~g} \cdot \mathrm{kg}^{-1}$.

\section{Data processing and analysis}

Data processing were carried out with Microsoft Excel 2019. The analysis of variance was performed by SPSS 22.0 statistical software. One way ANOVA and LSD were used to test the significance of multiple comparison differences $(\alpha=0.05)$. Fu et al. (2019) proposed the calculation method of soil porosity $(P)$ :

$$
P=1-\gamma_{d} / 2.65
$$

where, $\gamma_{d}$ is soil bulk density $\left(\mathrm{g} \cdot \mathrm{kg}^{-3}\right)$.

\section{Results}

\section{Effects of gypsum combined with different amounts of BHA on soil porosity}

Gypsum combined with different amounts of BHA treatment significantly increased soil porosity as a whole (Fig. 1). With the increase of the proportion of gypsum combined with BHA, the soil porosity showed an increasing trend $(\mathrm{C}>\mathrm{B}>\mathrm{A})$. The soil porosity of $0-10 \mathrm{~cm}$ soil layer increased by $16.00 \%, 23.61 \%$ and $35.03 \%$, respectively compared with single application of gypsum. The soil porosity in 10-20 cm soil layer increased by $14.05 \%, 4.45 \%$ and $1.26 \%$, respectively compared with single application of gypsum. The soil porosity in $20-40 \mathrm{~cm}$ soil layer increased by $7.63 \%, 7.66 \%$ and $2.55 \%$, respectively, compared with single application of gypsum. There was no significant difference in soil porosity among treatments A, B and C in 40-60 cm soil layer $(p>0.05)$. 


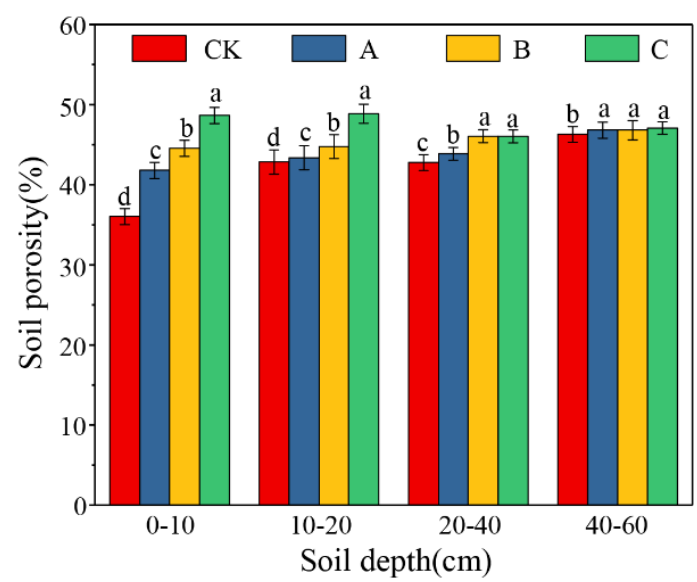

Figure 1. Influence of gypsum combined with different amount of BHA on soil porosity. CK represents single application of gypsum $15 t \cdot h a^{-1}$, A represents gypsum $15 t \cdot h a^{-1}+B H A 0.35$ $t \cdot h a^{-1}, B$ represents gypsum $15 t \cdot h a^{-1}+B H A 0.75 t \cdot h a^{-1}$, and C represents gypsum $15 t \cdot h a^{-1}+$ $B H A 1.50 t \cdot h a^{-1}$. The error lines represent the standard variance, and different lowercase letters represent significant differences among treatments in the same soil layer $(p<0.05)$

\section{The effect of gypsum combined with different amounts of BHA on soil aggregate}

Gypsum combined with different amounts of BHA increased the proportion of large aggregates $(>0.25 \mathrm{~mm})$ in plough layer $(0-10 \mathrm{~cm}$ and $10-20 \mathrm{~cm})$ soil and $20-40 \mathrm{~cm}$ soil layer, and decreased the proportion of small aggregates $(0.053-0.25 \mathrm{~mm})$ and micro aggregates $(<0.053 \mathrm{~mm}$ ) (Table 2). Gypsum combined with BHA had the most significant effect on the increase of the proportion of aggregates $>0.25 \mathrm{~mm}$ in the cultivated soil, and the increase effect showed a weakening trend with the increase of soil depth $(p<0.05)$. The proportion of large aggregates in $0-10 \mathrm{~cm}$ and $10-20 \mathrm{~cm}$ soil layers increased by $10.00 \%, 20.33 \%, 33.68 \%$ and $7.39 \%, 20.61 \%$ and $25.00 \%$, respectively, compared with single application of gypsum. In $0-40 \mathrm{~cm}$ soil layer, the proportion of large aggregates was $\mathrm{C}>\mathrm{B}>\mathrm{A}$, and there was significant difference among treatments $(p<0.05)$. There was no significant difference in the proportion of large aggregates among treatments A, B and C in 40-60 cm soil layer ( $p>0.05)$.

\section{The effect of gypsum combined with different amounts of BHA on soil pH}

The treatment of gypsum combined with different amounts of BHA significantly reduced the $\mathrm{pH}$ value of soil than that of single application of gypsum (Fig. 2). In 0-10 cm soil layer, with the increase of the amount of BHA, the soil $\mathrm{pH}$ value decreased first and then increased. Treatment B was the lowest, significantly lower than other treatments, and there was no significant difference between treatment $A$ and $C(p>0.05)$. In 10-20 cm soil layer, with the increase of the proportion of BHA, the soil $\mathrm{pH}$ value showed a downward trend. There was no significant difference between treatment $\mathrm{B}(p>0.05)$, treatment $\mathrm{A}$ and treatment $\mathrm{C}$, and treatment $\mathrm{A}$ was significantly greater than treatment $\mathrm{C}$ $(p<0.05)$. In $20-40 \mathrm{~cm}$ soil layer, treatment A was significantly higher than treatment B and $\mathrm{C}(p<0.05)$, and there was no significant difference between treatment $\mathrm{B}$ and $\mathrm{C}$ ( $p>0.05$ ). In 40-60 $\mathrm{cm}$ soil layer, with the increase of the proportion of BHA, the soil $\mathrm{pH}$ value showed a downward trend. There was no significant difference between treatment $\mathrm{A}$ and treatment $\mathrm{B}(p>0.05)$, but they were significantly higher than treatment $\mathrm{C}$ $(p<0.05)$. 
Table 2. Effects of gypsum combined with different amount of BHA on soil aggregates

\begin{tabular}{|c|c|c|c|c|}
\hline \multirow{2}{*}{ Soil depth (cm) } & \multirow{2}{*}{ Treatment } & \multicolumn{3}{|c|}{$\begin{array}{l}\text { Soil aggregates in different size }(\%) \\
\end{array}$} \\
\hline & & $>0.25 \mathrm{~mm}$ & $0.053-0.25 \mathrm{~mm}$ & $<0.053 \mathrm{~mm}$ \\
\hline \multirow{4}{*}{$0-10$} & $\mathrm{CK}$ & $57.89 \mathrm{~d}$ & $33.10 \mathrm{a}$ & $9.01 \mathrm{a}$ \\
\hline & A & $63.68 \mathrm{c}$ & $29.23 b$ & $7.09 \mathrm{~b}$ \\
\hline & B & $69.66 \mathrm{~b}$ & $26.60 \mathrm{c}$ & $3.74 \mathrm{c}$ \\
\hline & $\mathrm{C}$ & $77.39 \mathrm{a}$ & $20.00 \mathrm{~d}$ & 2.61d \\
\hline \multirow{4}{*}{$10-20$} & $\mathrm{CK}$ & $66.81 \mathrm{~d}$ & $25.17 \mathrm{a}$ & $8.02 \mathrm{a}$ \\
\hline & A & $71.75 \mathrm{c}$ & $21.17 \mathrm{~b}$ & $7.08 \mathrm{~b}$ \\
\hline & B & $80.58 \mathrm{~b}$ & $16.27 \mathrm{c}$ & $3.15 \mathrm{c}$ \\
\hline & $\mathrm{C}$ & $83.51 \mathrm{a}$ & $12.68 \mathrm{~d}$ & $3.81 \mathrm{c}$ \\
\hline \multirow{4}{*}{$20-40$} & $\mathrm{CK}$ & $47.97 \mathrm{~d}$ & $37.48 \mathrm{c}$ & $14.55 \mathrm{a}$ \\
\hline & A & $50.66 \mathrm{c}$ & $39.42 b$ & $9.92 \mathrm{~b}$ \\
\hline & B & $52.69 \mathrm{~b}$ & $40.59 \mathrm{a}$ & $6.72 \mathrm{c}$ \\
\hline & $\mathrm{C}$ & $53.80 \mathrm{a}$ & $41.64 \mathrm{a}$ & $4.56 \mathrm{~d}$ \\
\hline \multirow{4}{*}{$40-60$} & $\mathrm{CK}$ & $20.65 \mathrm{a}$ & $63.03 \mathrm{a}$ & $16.32 \mathrm{c}$ \\
\hline & A & $19.43 \mathrm{a}$ & $60.33 b$ & $20.24 b$ \\
\hline & B & $20.05 \mathrm{a}$ & $59.70 \mathrm{~b}$ & $20.25 b$ \\
\hline & $\mathrm{C}$ & $19.24 \mathrm{a}$ & $57.78 \mathrm{c}$ & $22.98 \mathrm{a}$ \\
\hline
\end{tabular}

CK represents single application of gypsum $15 \mathrm{t}^{-\mathrm{ha}^{-1}}$, A represents gypsum $15 \mathrm{t}^{\mathrm{h}} \mathrm{ha}^{-1}+\mathrm{BHA} 0.35 \mathrm{t}^{-} \mathrm{ha}^{-1}$, B represents gypsum $15 \mathrm{t} \cdot \mathrm{ha}^{-1}+$ BHA $0.75 \mathrm{t} \cdot \mathrm{ha}^{-1}$, and C represents gypsum $15 \mathrm{t} \cdot \mathrm{ha}^{-1}+$ BHA $1.50 \mathrm{t} \cdot \mathrm{ha}^{-1}$. The different lowercase letters represent significant differences among treatments in the same soil layer $(\mathrm{p}<0.05)$

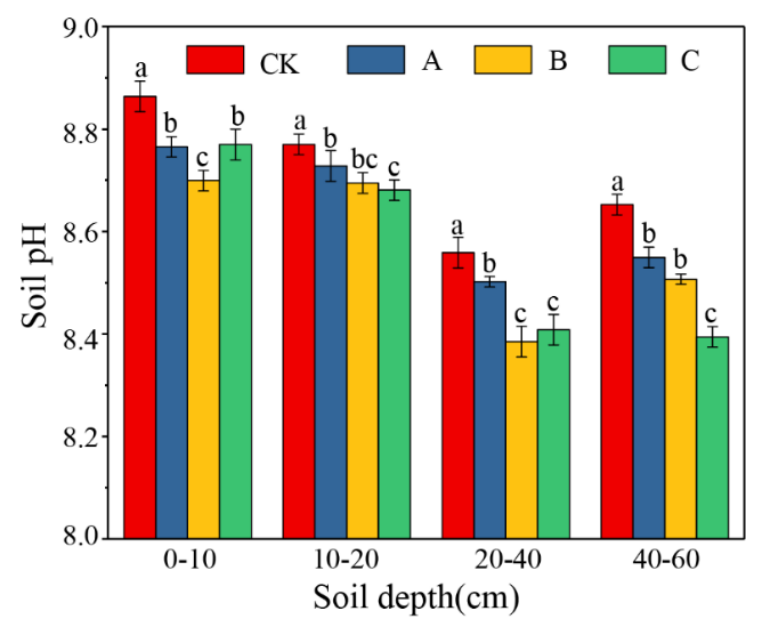

Figure 2. Influence of gypsum combined with different amount of BHA on soil $\mathrm{pH}$. CK represents single application of gypsum $15 t \cdot h a^{-1}$, A represents gypsum $15 t \cdot h a^{-1}+B H A 0.35$ $t \cdot h a^{-1}, B$ represents gypsum $15 t \cdot h a^{-1}+B H A 0.75 t \cdot h a^{-1}$, and C represents gypsum $15 t \cdot h a^{-1}+$ $B H A 1.50 t \cdot h a^{-1}$. The error lines represent the standard variance, and different lowercase letters represent significant differences among treatments in the same soil layer $(p<0.05)$

\section{The effect of effect of gypsum combined with different amounts of BHA on soil alkalinity}

In 0-10 cm soil layer, there was no significant difference between treatment $A$ and gypsum treatment, but it was significantly higher than treatment $\mathrm{B}$ and $\mathrm{C}$, and treatment C was significantly lower than other treatments (Fig. 3). In 10-20 cm soil layer, treatment A was significantly higher than that of single application of gypsum and treatment B and 
C $(p<0.05)$, the difference between each treatment was significant $(p<0.05)$, and treatment $C$ was the lowest. In 20-40 cm soil layer, the treatment of gypsum combined with BHA was significantly lower than that of single application of gypsum $(p<0.05)$, and with the increase of the proportion of BHA, the soil alkalinity showed a downward trend. There was no significant difference between treatment B $(p>0.05)$, treatment A and treatment $\mathrm{C}$, and treatment $\mathrm{A}$ was significantly greater than that of treatment $\mathrm{C}$ $(p<0.05)$. There was no significant difference among treatments in 40-60 cm soil layer $(p>0.05)$.

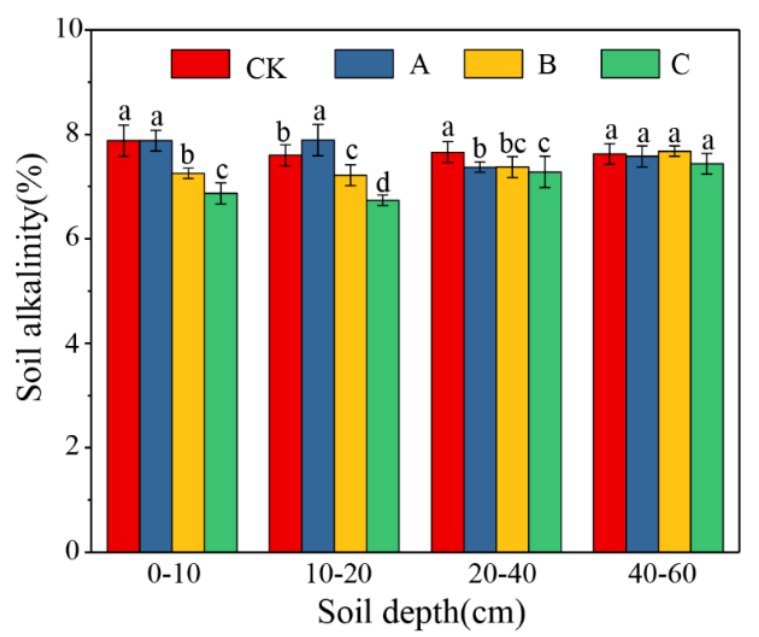

Figure 3. Influence of gypsum combined with different amount of BHA on soil alkalinity. $C K$ represents single application of gypsum $15 t \cdot h a^{-1}$, A represents gypsum $15 t \cdot h a^{-1}+B H A 0.35$ $t \cdot h a^{-1}, B$ represents gypsum $15 t \cdot h a^{-1}+B H A 0.75 t \cdot h a^{-1}$, and C represents gypsum $15 t \cdot h a^{-1}+$ $B H A 1.50 t \cdot h a^{-1}$. The error lines represent the standard variance, and different lowercase letters represent significant differences among treatments in the same soil layer $(p<0.05)$

\section{The effect of gypsum combined with different amounts of BHA on soil electric conductibility}

Gypsum combined with BHA treatments significantly reduced the electric conductivity of $0-10 \mathrm{~cm}, 10-20 \mathrm{~cm}$ and $20-40 \mathrm{~cm}$ soil layers (Fig. 4). In 0-10 cm soil layer, there were significant differences among treatments $(p<0.05)$. With the increase of the application amount of BHA, the soil electric conductivity showed a decreasing trend. Treatment A, B and C decreased by $51.25 \%, 66.80 \%$ and $70.00 \%$, respectively, compared with the treatment of single application of gypsum. In $10-20 \mathrm{~cm}$ soil layer, with the increase of BHA application rate, the soil electric conductivity showed a decreasing trend, and there was no significant difference between treatment $\mathrm{B}$ and treatment $\mathrm{C}(p>0.05)$. In 20-40 cm soil layer, with the increase of the amount of BHA, there was no significant difference between $\mathrm{CK}$ and treatment $\mathrm{A}$ and $\mathrm{B}(p>0.05)$, while treatment $\mathrm{A}$ was significantly higher than treatment $\mathrm{B}$ and $\mathrm{C}(p<0.05)$, and there was no significant difference between treatment B and C ( $p>0.05)$. In the soil layer of 40-60 cm, with the increase of the application amount of BHA, the soil electric conductivity decreased first and then increased. There was no significant difference between $\mathrm{CK}$ and treatment $\mathrm{A}$ and $\mathrm{B}(p>0.05)$, while there was significant difference between treatment $\mathrm{A}, \mathrm{B}$ and $\mathrm{C}$ $(p<0.05)$, and treatment $\mathrm{C}$ was the highest. 


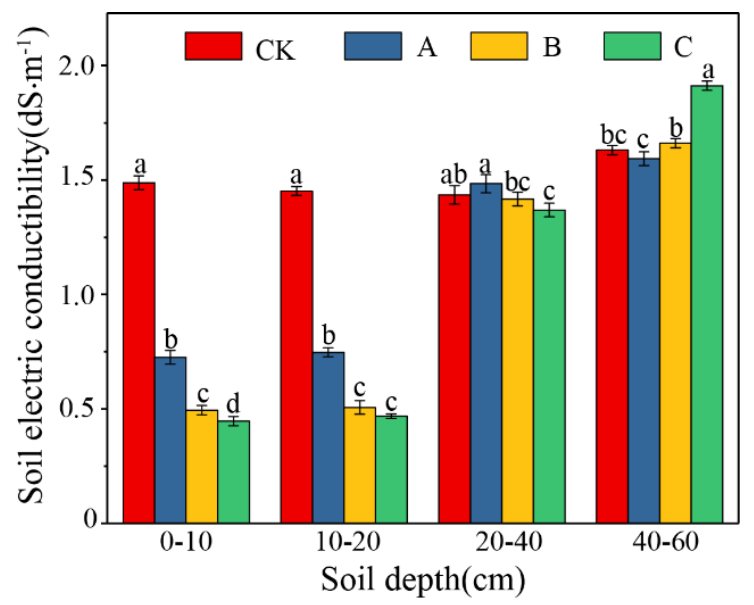

Figure 4. Influence of gypsum combined with different amount of BHA on soil electric conductibility. CK represents single application of gypsum $15 t \cdot h a^{-1}$, A represents gypsum 15 $t \cdot h a^{-1}+B H A 0.35 t \cdot h a^{-1}, B$ represents gypsum $15 t \cdot h a^{-1}+B H A 0.75 t \cdot h a^{-1}$, and C represents gypsum $15 t \cdot h a^{-1}+B H A 1.50 t \cdot h a^{-1}$. The error lines represent the standard variance, and different lowercase letters represent significant differences among treatments in the same soil layer $(p<0.05)$

\section{The effect of gypsum combined with different amounts of BHA on soil cation}

In 0-10 $\mathrm{cm}$ and $20-40 \mathrm{~cm}$ soil layers, the $\mathrm{K}^{+}$content of gypsum combined with BHA treatment was significantly lower than that of gypsum treatment alone, and the $\mathrm{C}$ treatment was the lowest (Fig. 5a). Each treatment decreased by $12.35 \%, 12.47 \%$, $26.18 \%$ and $33.45 \%, 30.99 \%$ and $38.50 \%$, respectively, compared with the control. In $10-20 \mathrm{~cm}$ soil layer, the $\mathrm{K}^{+}$content of each treatment was significantly higher than that of gypsum treatment alone $(p<0.05)$. Treatment $\mathrm{A}$ was the highest, with an increase of $48.31 \%$, and treatment $C$ was significantly lower than that of treatment a but significantly higher than that of treatment B $(p<0.05)$. In 40-60 cm soil layer, the $\mathrm{K}^{+}$content of each treatment increased significantly, but the increase was small $(p<0.05)$. In the soil layer of $0-10 \mathrm{~cm}$, the $\mathrm{Ca}^{2+}$ content of treatment $\mathrm{A}$ was significantly higher than that of treatment with single application of gypsum $(p<0.05)$, increased by $3.88 \%$, treatment B was significantly lower than that of treatment $\mathrm{A}$ and treatment with single application of gypsum $(p<0.05)$, and the $\mathrm{Ca}^{2+}$ content was $6.61 \%$ lower than that of treatment with single application of gypsum (Fig. 5b). There was no significant difference between treatment $\mathrm{C}$ and treatment with single application of gypsum, but it was significantly higher than that of treatment $\mathrm{B}(p<0.05)$. In the soil layer of $20-40 \mathrm{~cm}$, the $\mathrm{Ca}^{2+}$ content of treatment A, B and C was significantly higher than that of single application of gypsum $(p<0.05)$. There was no significant difference between treatment A and B, but it was significantly lower than that of treatment C. In 40-60 $\mathrm{cm}$ soil layer, there was no significant difference among gypsum treatment, $\mathrm{A}$ and $\mathrm{C}$ treatment, but they were significantly lower than B treatment ( $p>0.05$, Fig. 5c). B treatment increased by $45.51 \%$ compared with gypsum treatment. In the soil layers of $0-10,10-20 \mathrm{~cm}$ and $20-40 \mathrm{~cm}$, the $\mathrm{Na}^{+}$content of gypsum combined with BHA treatment was significantly lower than that of single application of gypsum $(p<0.05)$. With the increase of the application amount of BHA, the $\mathrm{Na}^{+}$content showed a downward trend. There was no significant difference between treatments B and C in $0-10 \mathrm{~cm}$ soil layer $(p>0.05)$, but it was significantly lower than that of treatment $\mathrm{A}(p<0.05)$. There were significant differences between treatments 
in 10-20 $\mathrm{cm}$ and $20-40 \mathrm{~cm}$ soil layer $(p<0.05)$. In 40-60 $\mathrm{cm}$ soil layer, there was no significant difference between treatment $\mathrm{A}$ and gypsum treatment alone $(p>0.05)$. With the increase of the amount of BHA, the $\mathrm{Na}^{+}$content showed an increasing trend. There were significant differences among soil $\mathrm{Mg}^{2+}$ treatments in 0-10 and 10-20 cm soil layer $(p<0.05)$, and it showed an increasing trend with the increase of the amount of BHA (Fig. 5d). The content of $\mathrm{Mg}^{2+}$ in 20-40 cm soil layer was significantly higher than that in gypsum treatment alone $(p<0.05)$, and the increase range was $\mathrm{B}>\mathrm{A}>\mathrm{C}$. The change of soil $\mathrm{Mg}^{2+}$ content in 40-60 cm soil layer changed slightly ( $\left.p>0.05\right)$.
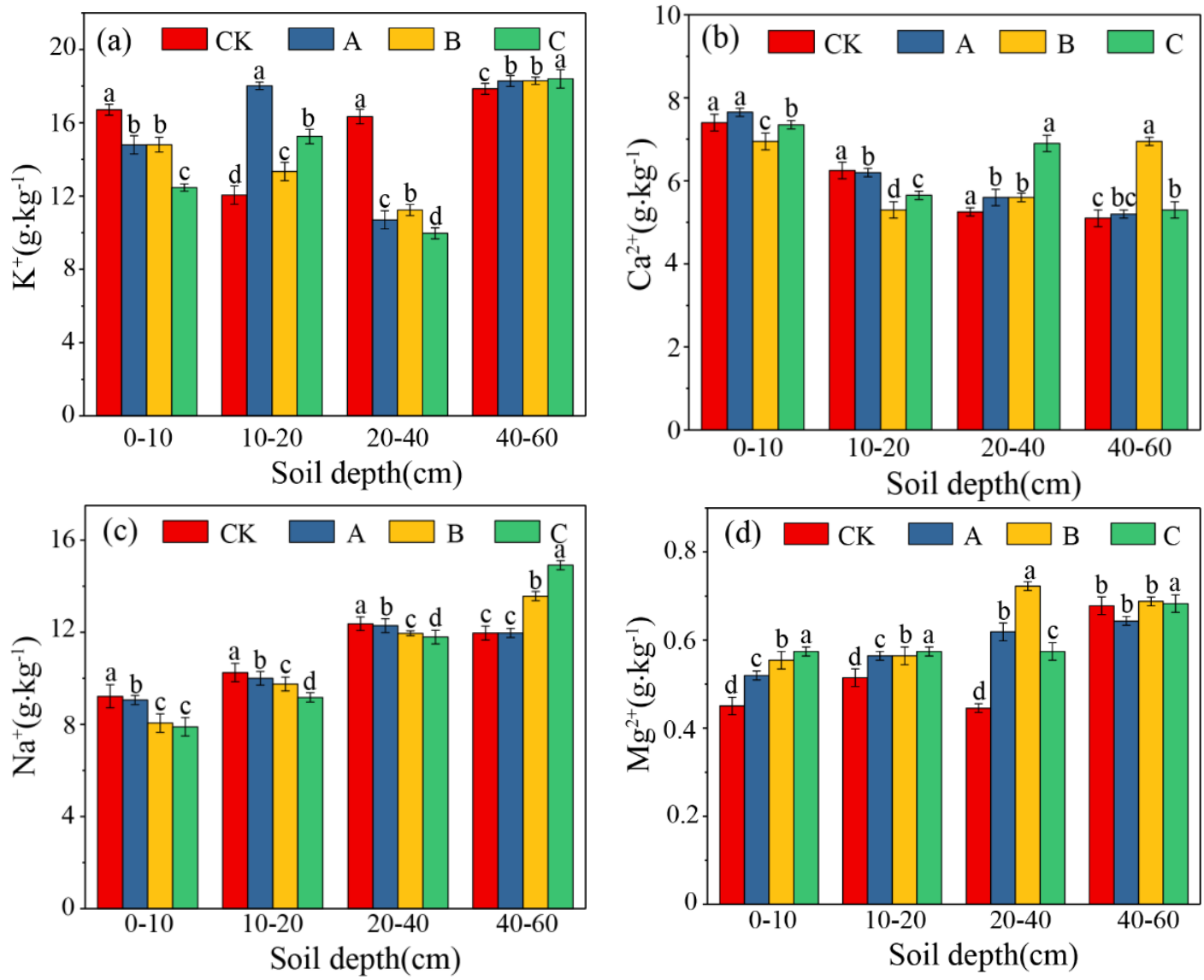

Figure 5. Influence of gypsum combined with different amount of BHA on soil cation. $C K$ represents single application of gypsum $15 t \cdot h a^{-1}$, A represents gypsum $15 t \cdot h a^{-1}+B H A 0.35$ $t \cdot h a^{-1}, B$ represents gypsum $15 t \cdot h a^{-1}+B H A 0.75 t \cdot h a^{-1}$, and C represents gypsum $15 t \cdot h a^{-1}+$ $B H A 1.50 t \cdot h a^{-1}$. The error lines represent the standard variance, and different lowercase letters represent significant differences among treatments in the same soil layer $(p<0.05)$

\section{The effect of gypsum combined with different amounts of BHA on cotton yield}

The difference of cotton yield under each treatment was analyzed (Fig. 6). Treatment $\mathrm{A}, \mathrm{B}$ and $\mathrm{C}$ obviously increased the cotton yield. The difference of cotton yield between treatment $\mathrm{C}$ was significantly higher than that of other treatments $(p<0.05)$. The combined application of gypsum and BHA was better than that of alone $(p<0.05)$. The cotton yield of treatment A, B and C improved by $5.86 \%, 12.50 \%$ and $18.13 \%$, respectively, compared with the treatment of single application of gypsum. 


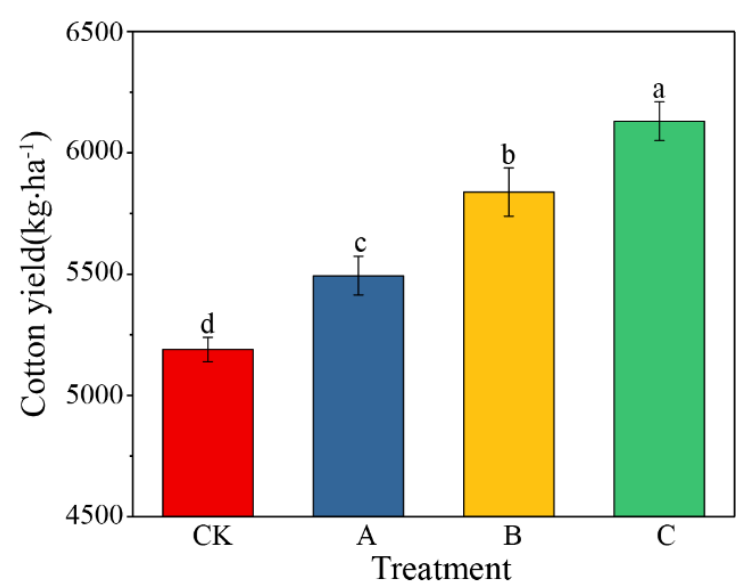

Figure 6. Influence of different amount of BHA combined with gypsum on cotton yield. CK represents single application of gypsum $15 t \cdot h a^{-1}$, A represents gypsum $15 t \cdot h a^{-1}+B H A 0.35$ $t \cdot h a^{-1}, B$ represents gypsum $15 t \cdot h a^{-1}+B H A 0.75 t \cdot h a^{-1}$, and C represents gypsum $15 t \cdot h a^{-1}+$ $B H A 1.50 t \cdot h a^{-1}$. The error lines represent the standard variance, and different lowercase letters represent significant differences among treatments in the same soil layer $(p<0.05)$

\section{Discussion}

The combination of gypsum and different amount of BHA can improve soil physicochemical properties

Our results showed that the combined application of gypsum and different amounts of biochemical humic acid (BHA) increased the percentage of large aggregates and decreased the percentage of small and micro aggregates in the topsoil soil $(0-40 \mathrm{~cm}$, Table 2). The increase order of large aggregates was $\mathrm{C}$ (gypsum $15 \mathrm{t} \cdot \mathrm{ha}^{-1}+\mathrm{BHA}$ $\left.1.50 \mathrm{t} \cdot \mathrm{ha}^{-1}\right)>\mathrm{B}\left(\right.$ gypsum $15 \mathrm{t} \cdot \mathrm{ha}^{-1}+$ BHA $\left.0.75 \mathrm{t} \cdot \mathrm{ha}^{-1}\right)>$ A (gypsum $15 \mathrm{t} \cdot \mathrm{ha}^{-1}+\mathrm{BHA}^{-1}$ $\left.0.35 \mathrm{t} \cdot \mathrm{ha}^{-1}\right)$. The effect of combined application of gypsum and BHA on soil porosity (Fig. 1) and aggregates (Table 2) was significantly higher than that of single application of gypsum $(p<0.05)$. Different combined application schemes significantly improve the content of large aggregates $(>0.25 \mathrm{~mm})$ in soil $(p<0.05)$. Chen et al. (2020) reported that with the increase of gypsum application, the content of soil water stable aggregates increased significantly. It is concluded that $\mathrm{Ca}^{2+}$ produced by gypsum directly participates in the formation of soil organic-inorganic complex, which is an important mechanism for the improvement of alkaline soil aggregate structure (Knevitz et al., 2021). With the increase of the amount of gypsum and BHA, the soil porosity showed an increasing trend, and the soil porosity increased significantly under the maximum amount of gypsum and BHA (Fig. 1). Han et al. (2016) also found that the mixed modifier of gypsum and humic acid increased the total soil porosity by $0.16 \%-10.52 \%$ compared with the basic soil. Our results showed that the total soil porosity increased with the increase of modifier application, showing a significant positive correlation (Fig. 1). In this study, the $\mathrm{pH}$ (Fig. 2), alkalinity (Fig. 3) and electric conductivity (Fig. 4) of topsoil soil decreased significantly after the combined application of gypsum and BHA $(p<0.05)$, which is consistent with the conclusion that the application of modifier in soil significantly reduced the $\mathrm{pH}$ value and alkalinity of soil found by Koralegedara et al. (2017) and Li et al. (2012). The reason is that $\mathrm{Na}^{+}$in soil colloid is replaced by $\mathrm{Ca}^{2+}$ in gypsum, which reduces the salt and alkali content in soil and leaches it in combination with irrigation to achieve the 
purpose of soil improvement (Watts and Dick, 2014; Mao et al., 2015). Our results showed that after the combined application of gypsum and BHA, the soil electric conductivity of $0-40 \mathrm{~cm}$ soil layer decreased and that of $40-60 \mathrm{~cm}$ soil layer increased (Fig. 4). This may be due to the increase of porosity, water permeability and air permeability of soil surface layer caused by the application of gypsum and BHA (Armando et al., 2021). With irrigation and leaching, salt moves underwater and accumulates in the lower layer $(40-60 \mathrm{~cm})$, it leads to the increase of soil electric conductivity. The decrease of $\mathrm{Na}^{+}$content in $0-20 \mathrm{~cm}$ soil layer was the largest (Fig. 5b), because $\mathrm{Ca}^{2+}$ provided by gypsum replaces $\mathrm{Na}^{+}$adsorbed on soil colloid. The decrease of $\mathrm{Ca}^{2+}$ content (Fig. 5c) may be due to the replacement reaction between $\mathrm{Ca}^{2+}$ and $\mathrm{Na}^{+}$, resulting in the precipitation reaction between $\mathrm{Ca}^{2+}$ and $\mathrm{HCO}_{3}{ }^{-}$and $\mathrm{CO}_{3}{ }^{2-}$ in the soil, which reduces the content of soil $\mathrm{Ca}^{2+}$ (Zhu et al., 2020). The content of $\mathrm{Mg}^{2+}$ in soil increased (Fig. 5d), which was mainly related to the chemical exchange of $\mathrm{Na}^{+}$and $\mathrm{Mg}^{2+}$ (Cera et al., 2021).

\section{The combination of gypsum and different amount of BHA increase the cotton yield}

Numerous investigations suggest shows that gypsum has fine particles and low water content, which can be directly applied to saline-alkali soil to accelerate desalination, improve soil structure and increase soil permeability (Aydemir and Najjar, 2005; Yu et al., 2014; Koralegedara et al., 2019; Liu et al., 2021; Zhang et al., 2021). In addition, gypsum contains a large number of trace and nutrient elements, which can also promote plant growth and improve the emergence rate and yield of crops in saline alkali land (Wang et al., 2017b; Zhao et al., 2018; Cao et al., 2019). In this study, with the increase of the amount of gypsum combined with BHA, the cotton yield showed an increasing trend, reaching the maximum when gypsum $15 \mathrm{t} \cdot \mathrm{ha}^{-1}$ and BHA $1.50 \mathrm{t} \cdot \mathrm{ha}^{-1}$ was applied (Fig. 6). The effect of gypsum combined with BHA on cotton yield was better than that of single application $(p<0.05)$. At the same time, Ali et al. (2018) showed that the combined application of humic acid provided sufficient nutrients for soil and crops, improved the disease resistance of crops, and increased the yield of cabbage and maize. Wong et al. (2009) found that the application of gypsum modifier in saline-alkali land could significantly improve the emergence rate and fresh grass yield of alfalfa. On the one hand, the application of gypsum and BHA participate in the formation of soil aggregate structure, improves soil aggregate structure (Kim et al., 2017), and adjusts soil $\mathrm{pH}$. On the other hand, the application of gypsum increases $\mathrm{S}, \mathrm{Ca}, \mathrm{Si}$ and other elements beneficial to plant growth, improves plant resistance to harsh environment, improves nutrient deficiency, which is beneficial to crop growth (Mailapalli and Thompson, 2011).

In summary, the combined application mode of gypsum $15 \mathrm{t} \cdot \mathrm{ha}^{-1}$ and BHA $1.50 \mathrm{t} \cdot \mathrm{ha}^{-1}$ is more suitable for agricultural production. The combined application of gypsum and BHA can solve the problem of industrial waste treatment and optimize the utilization of resources.

\section{Conclusions}

1) Gypsum combined with different amounts of biochemical humic acid (BHA) had an obvious effect on the increase of soil porosity and the number of large aggregates.

2) After applying gypsum and BHA, the $\mathrm{pH}$ value, alkalinity and electric conductivity of topsoil soil decreased, and the combined application effect was better than that of single application of gypsum. 
However, as an industrial waste, gypsum contains a certain amount of heavy metals. Whether long-term application will cause some environmental problems has not been studied clearly. Therefore, how to further improve cotton yield on the basis of improving saline-alkali land without causing environmental pollution is a problem that we will continue to pay attention to and study in the future.

Acknowledgements. This work was supported by the Major Special Science and Technology Project of Xinjiang Province (2020A01002-1).

\section{REFERENCES}

[1] Ali, S., Jan, A., Manzoor, Sohail, A., Khan, A., Khan, M. I., Inamullah, Zhang, J., Daur, I. (2018): Soil amendments strategies to improve water-use efficiency and productivity of maize under different irrigation conditions. - Agricultural Water Management 210: 88-95.

[2] Armando, V., Dazzi, C., Delgado, A., Barros, H., Scalenghe, R., Sim, U. (2021): Relief and calcium from gypsum as key factors for net inorganic carbon accumulation in soils of a semiarid Mediterranean environment. - Geoderma 398: 115115.

[3] Aydemir, S., Najjar, N. F. (2005): Application of two amendments (gypsum and langbeinite) to reclaim sodic soil using sodic irrigation water. - Australian Journal of Soil Research 43: 547-553.

[4] Cao, Y., Gao, Y., Li, J., Tian, Y. (2019): Straw composts, gypsum and their mixtures enhance tomato yields under continuous saline water irrigation. - Agricultural Water Management 223: 105721.

[5] Cera, A., Montserrat-Martí, G., Pedro, J., Drenovsky, R. E., Palacio, S. (2021): Gypsumexclusive plants accumulate more leaf $\mathrm{S}$ than non-exclusive species both in and off gypsum. - Environmental and Experimental Botany 182: 104294.

[6] Chen, X. D., Yaa, O. K., Wu, J. (2020): Effects of different organic materials application on soil physicochemical properties in a primary saline-alkali soil. - Eurasian Soil Science 53: 798-808.

[7] Fu, Y., Tian, Z., Amoozegar, A., Heitman, J. (2019): Measuring dynamic changes of soil porosity during compaction. - Soil and Tillage Research 193: 114-121.

[8] Han, Y. S., Tokunaga, T. K., Salve, R., Chon, C. M. (2016): Environmental feasibility of soil amendment with flue gas desulfurization gypsum (FGDG) for terrestrial carbon sequestration. - Environmental Earth Sciences 75: 1-9.

[9] Heng, T., Liao, R., Wang, Z., Wu, W., Li, W., Zhang, J. (2018): Effects of combined drip irrigation and sub-surface pipe drainage on water and salt transport of saline-alkali soil in Xinjiang, China. - Journal of Arid Land 10: 932-945.

[10] Kim, Y., Choo, B., Cho, J. (2017): Effect of gypsum and rice straw compost application on improvements of soil quality during desalination of reclaimed coastal tideland soils: Ten years of long-term experiments. - Catena 156: 131-138.

[11] Knevitz, R., Basso, D., Laerson, G., Mallmann, K. (2021): Limestone and gypsum reapplication in an oxisol under no-tillage promotes low soybean and corn yield increase under tropical conditions. - Soil and Tillage Research 214: 105165.

[12] Koralegedara, N. H., Al-Abed, S. R., Rodrigo, S. K., Karna, R. R., Scheckel, K. G., Dionysiou, D. D. (2017): Alterations of lead speciation by sulfate from addition of flue gas desulfurization gypsum (FGDG) in two contaminated soils. - Science of The Total Environment 575: 1522-1529.

[13] Koralegedara, N. H., Pinto, P. X., Dionysiou, D. D., Al-Abed, S. R. (2019): Recent advances in flue gas desulfurization gypsum processes and applications - A review. Journal of environmental management 251: 109572. 
[14] Li, M., Jiang, L., Sun, Z., Wang, J., Rui, Y., Zhong, L., Wang, Y., Kardol, P. (2012): Effects of flue gas desulfurization gypsum by-products on microbial biomass and community structure in alkaline-saline soils. - Journal of Soils and Sediments 12: 1040-1053.

[15] Liang, J., Li, Y., Si, B., Wang, Y., Chen, X., Wang, X., Chen, H., Wang, H., Zhang, F., Bai, Y., Biswas, A. (2021): Optimizing biochar application to improve soil physical and hydraulic properties in saline-alkali soils. - Science of the Total Environment 771: 144802.

[16] Liu, M., Wang, C., Liu, X., Lu, Y., Wang, Y. (2020): Saline-alkali soil applied with vermicompost and humic acid fertilizer improved macroaggregate microstructure to enhance salt leaching and inhibit nitrogen losses. - Applied Soil Ecology 156: 103705.

[17] Liu, S., Liu, W., Jiao, F., Qin, W., Yang, C. (2021): Production and resource utilization of flue gas desulfurized gypsum in China - A review. - Environmental Pollution 288: 117799.

[18] Mailapalli, D. R., Thompson, A. M. (2011): Polyacrylamide coated MilorganiteTM and gypsum for controlling sediment and phosphorus loads. - Agricultural Water Management 101: 27-34.

[19] Mao, G., Xu, X., Chen, Q., Yue, Z., Zhu, L. (2014). Flue gas desulfurization gypsum byproducts alters cytosolic $\mathrm{Ca}^{2+}$ distribution and $\mathrm{Ca}^{2+}$-ATPase activity in leaf cells of oil sunflower in alkaline soil. - Journal of Plant Interactions 9: 152-158.

[20] Mao, Y., Li, X., Dick, W. A., Chen, L. (2015): Remediation of saline-sodic soil with flue gas desulfurization gypsum in a reclaimed tidal flat of southeast China. - Journal of Environmental Sciences 45: 224-232.

[21] Nan, J., Chen, X., Wang, X., Lashari, M. S., Wang, Y., Guo, Z., Du, Z. (2016): Effects of applying flue gas desulfurization gypsum and humic acid on soil physicochemical properties and rapeseed yield of a saline-sodic cropland in the eastern coastal area of China. - Journal of Soils and Sediments 16: 38-50.

[22] Sakai, Y., Matsumoto, S., Sadakata, M. (2004): Alkali soil reclamation with flue gas desulfurization gypsum in China and assessment of metal content in corn grains. - Soil and Sediment Contamination 13: 65-80.

[23] Wang, Q., Men, L., Gao, L., Tian, Y. (2017a): Effect of grafting and gypsum application on cucumber (Cucumis sativus L.) growth under saline water irrigation. - Agricultural Water Management 188: 79-90.

[24] Wang, S. J., Chen, Q., Li, Y., Zhuo, Y. Q., Xu, L. Z. (2017b): Research on saline-alkali soil amelioration with FGD gypsum. - Resources, Conservation and Recycling 121: 8292.

[25] Wang, X., Wang, J., Wang, J. P. (2021): Seasonality of soil respiration under gypsum and straw amendments in an arid saline-alkali soil. - Journal of Environmental Management 277: 111494.

[26] Watts, D. B., Dick, W. A. (2014): Sustainable uses of FGD gypsum in agricultural systems: introduction. - Journal of Environmental Quality 43: 246-252.

[27] Wong, V. N. L., Dalal, R. C., Greene, R. S. B. (2009): Carbon dynamics of sodic and saline soils following gypsum and organic material additions: A laboratory incubation. - Applied Soil Ecology 41: 29-40.

[28] Xia, J., Ren, J., Zhang, S., Wang, Y., Fang, Y. (2019): Forest and grass composite patterns improve the soil quality in the coastal saline-alkali land of the Yellow River Delta, China. - Geoderma 349: 25-35.

[29] Yan, F., Zhang, F., Fan, J., Hou, X., Bai, W., Liu, X., Wang, Y., Pan, X. (2021): Optimization of irrigation and nitrogen fertilization increases ash salt accumulation and ions absorption of drip-fertigated sugar beet in saline-alkali soils. - Field Crops Research 271: 108247.

[30] Yu, H., Yang, P., Lin, H., Ren, S., He, X. (2014): Effects of sodic soil reclamation using flue gas desulphurization gypsum on soil pore characteristics, bulk density, and saturated hydraulic conductivity. - Soil Science Society of America Journal 78: 1201-1213. 
[31] Zhang, Y., Yang, J., Yao, R., Wang, X., Xie, W. (2020): Short-term effects of biochar and gypsum on soil hydraulic properties and sodicity in a saline-alkali soil. - Pedosphere 30: 694-702.

[32] Zhang, W., Zhang, W., Wang, S., Liu, J., Li, Y., Zhuo, Y., Xu, L., Zhao, Y. (2021): Band application of flue gas desulfurization gypsum improves sodic soil amelioration. - Journal of Environmental Management 298: 113535.

[33] Zhao, Y., Wang, S., Li, Y., Liu, J., Zhuo, Y., Zhang, W., Wang, J., Xu, L. (2018): Longterm performance of flue gas desulfurization gypsum in a large-scale application in a saline-alkali wasteland in northwest China. - Agriculture, Ecosystems and Environment 261: $115-124$.

[34] Zhao, Y., Wang, S., Li, Y., Zhuo, Y., Liu, J. (2019): Effects of straw layer and flue gas desulfurization gypsum treatments on soil salinity and sodicity in relation to sunflower yield. - Geoderma 352: 13-21.

[35] Zhao, Y., Li, Y., Wang, S., Wang, J., Xu, L. (2020): Combined application of a straw layer and flue gas desulphurization gypsum to reduce soil salinity and alkalinity. - Pedosphere 30: 226-235.

[36] Zhou, B., Yang, L., Chen, X., Ye, S., Peng, Y., Liang, C. (2021): Effect of magnetic water irrigation on the improvement of salinized soil and cotton growth in Xinjiang. Agricultural Water Management 248: 106784.

[37] Zhu, H., Yang, J., Yao, R., Wang, X., Xie, W., Zhu, W., Liu, X., Cao, Y., Tao, J. (2020): Interactive effects of soil amendments (biochar and gypsum) and salinity on ammonia volatilization in coastal saline soil. - Catena 190: 104527. 